\title{
Competitive coexistence of the dorid nudibranchs Doridella steinbergae and Corambe pacifica
}

\author{
Paul M. Yoshioka \\ Department of Marine Sciences, University of Puerto Rico, Mayaguez, Puerto Rico 00708, USA
}

\begin{abstract}
The roles of resource partitioning and environmental variability in the competitive coexistence of the dorid nudibranchs Doridella steinbergae and Corambe pacifica are examined in this study. These species co-occur episodically in southern California Macrocystis kelp beds during periods of high abundances of their bryozoan prey, Membranipora membranacea. Veligers of both species settle prior to peak prey densities because of the higher age-specific prey requirements of older nudibranchs. C. pacifica settles before $D$. steinbergae during periods of nudibranch occurrence because of longer development times. Coupled with age-specific feeding rates, this difference in appearance increases the potential for competition by maximizing the concurrent demand for prey by both species, and therefore contradicts the expectations of resource partitioning theory. Spatial and temporal variations in the relative abundance of prey can account for the coexistence of the nudibranchs. Prey abundances span the range from insufficient (no nudibranch reproduction possible), to limiting (some reproduction possible), to overabundant (maximum reproduction possible). These variations allow the relative advantages of both $D$. steinbergae (reproductive efficiency) and C. pacifica (fecundity) to be expressed.
\end{abstract}

\section{INTRODUCTION}

In this report I examine the competitive coexistence of 2 dorid nudibranchs, Doridella steinbergae Lance and Corambe pacifica MacFarland \& O'Donoghue. These species are remarkably similar in many aspects of their ecology: both (1) feed exclusively on a single prey species, the bryozoan Membranipora membranacea; (2) have dorsal coloring patterns closely resembling the zooid structure of $M$. membranacea; (3) co-occur on the macroalgal habitats of their prey (principally the giant kelp Macrocystis pyrifera in southern California); and (4) have identical geographical distributions along the west coast of North America (MacFarland \& O'Donoghue 1929, Lance 1961, 1962, McBeth 1968, Seed 1976, Yoshioka 1982a, Harvell 1984). Differences noted between the nudibranchs include the greater (1) fecundity (25000 versus 12000 eggs) (2) size (1.3 versus $0.82 \mathrm{~cm}$ ), (3) feeding rates (500 versus 80 zooids $\mathrm{d}^{-1}$ for mature individuals), (4) food requirements (lifetime consumption of 10000 versus 800 zooids), and (5) development time (26 versus $17 \mathrm{~d}$ after settlement) of C. pacifica compared to D. steinbergae (Yoshioka 1986).

Previous reports indicate that prey resources may be occasionally limiting, hence that competition may occur between the nudibranchs. For instance, Lance (1962) and Yoshioka (1973) have noted large numbers ( 100 individuals) of Doridella steinbergae and Corambe pacifica on single kelp blades. $D$. steinbergae is the superior competitor in terms of (1) locating dispersed zooids and (2) reproduction relative to zooid consumption (Yoshioka 1986). No inter- or intraspecific interactions (exclusive of copulation) have been observed between nudibranchs suggesting that competition involves exploitation rather than interference mechanisms (Yoshioka 1986).

In this report I first describe the spatial and temporal distribution of Membranipora membranacea prey populations. I then examine 2 alternative explanations, resource partitioning and environmental variability, which appear relevant to the competitive coexistence of Doridella steinbergae and Corambe pacifica.

The case for resource partitioning is supported by indications of a close coevolutionary relation between predator and prey, including: (1) the specialized feeding habits and (2) physical appearance of the nudibranchs; as well as (3) the production of spines by Membranipora membranacea zooids as a protective mechanism when exposed to predation by these 
nudibranchs (Yoshioka 1982a, Harvell 1984). These considerations suggest that Doridella steinbergae and Corambe pacifica have interacted over evolutionary time scales, a necessary condition for resource partitioning (e.g. Connell 1980). Schoener (1974) predicted that resource partitioning occurs by differences in (1) habitat, (2) food, and (3) time, in order of relative importance. The first 2 conditions are inapplicable to the nudibranchs, and in apparent agreement with prediction, I present evidence for temporal differences in the appearances of the nudibranchs. However, because theory may make the 'right prediction for the wrong reason' (Dayton 1973), I then evaluate the relevance of resource partitioning by determining (1) whether the temporal difference can be explained by an alternative hypothesis invloving the interaction of nudibranch life history pattern with the dynamics of their prey and (2) if competition is reduced between $D$. steinbergae and C. pacifica.

In terms of environmental variability, Doridella steinbergae, Corambe pacifica and Membranipora membranacea have complex life cycles with planktotrophic larval stages. Pelagic factors affecting the dispersal and survival of larvae may result in a highly variable relation between local reproduction and recruitment. For instance, recnuitment of $M$. membranacea can vary 10-fold in 2 wk (Yoshioka 1982b). Density-independent factors in the kelp canopy may cause further variations in population size (Bernstein \& Jung 1979). Because the nudibranchs utilize their prey by exploitation, the successful growth and reproduction of individual nudibranchs is highly dependent upon the supply of zooids relative to the demands of the nudibranchs. I therefore quantify the role of environmental variability by examining variations in supply/demand ratios as indexed by zooid densities relative to nudibranch abundance. I then assess the importance of environmental variability in the coexistence of the nudibranchs by determining whether the differential advantages of both $D$. steinbergae (reproductive efficiency) and $C$. pacifica (fecundity) can be expressed.

\section{METHODS}

Membranipora membranacea, Doridella steinbergae, and Corambe pacifica populations were monitored on blades subsampled from Macrocystis pyrifera fronds taken from a kelp bed about $5 \mathrm{~km}$ north of La Jolla, California. Each frond was divided into strata of 10 blades and 1 blade was randomly selected from each stratum (i.e. a stratified-random sampling strategy). From 3 to 5 fronds and 8 to 11 blades per frond were sampled at $2 \mathrm{wk}$ intervals over a $2 \mathrm{yr}$ period, conditions permitting. Nudibranchs and $M$. membrancea colonies were counted and measured in the laboratory. Colony ages were estimated from fieldderived growth rates. In cases where space limited the growth of colonies, 2 additional criteria were used to estimate age: (1) the extent to which a colony occupied the space available to it (e.g. growing into nooks and crannies'); and (2) the the condition of the growing edge - the lack of a 'milky fringe' indicated that growth had ceased for several days (Lutaud 1961). Zooid densities were calculated from colony size-zooid number relations and the size-frequency distribution of colonies.

Details of the temporal appearance of the nudibranchs were derived from kelp fronds suspended from the Scripps Institute pier. Individual blades were removed at 3 to $6 \mathrm{~d}$ intervals and characteristics of predator and prey populations were noted.

\section{RESULTS}

\section{Distribution of Membranipora membranacea}

General features of the distribution of Membranipora membranacea on kelp fronds and blades are illustrated by a representative sample in Table 1. The distribution of colonies arises largely from preferential cyphonautes settlement on recently mature $(\sim 2 \mathrm{mo}$ old) kelp blades. Colonies tend to be segregated among kelp blades by age (size) classes with older colonies being associated with older blades. Higher zooid densities generally occur on older blades due to larger colony size although this pattern may vary depending upon temporal fluctuations in colony recruitment and survival. Table 1 also demonstrates that variations in zoid densities are greater among individual blades within fronds than among frond totals, indicating that the frond as a whole 'integrates out' differences among blades of different ages. Doridella steinbergae and Corambe pacifica occur in kelp beds from January to June when prey populations reach their seasonal peak (Yoshioka 1982a, b). A representative example of temporal variations in zooid density during this period is shown in Fig. 1.

The spatial and temporal distribution of zooids reveals several factors critical to the success of individual nudibranchs. The nudibranchs are small and relatively immobile with respect to the size of kelp blades $(\sim 30$ to $50 \mathrm{~cm}$ in length). Thus, the kelp frond probably represents a series of discrete microhabitats (kelp blades), and prey resources available to individual nudibranchs would be best expressed on this basis. Temporal variations in zooid densities relevant to individual nudibranchs should then reflect changes occurring on individual blades rather than the kelp frond as a whole. 
Table 1. Membranipora membranacea. Representative distribution of colonies and zooids per blade on Macrocystis pyrifera fronds and blades. Blade ages are estimated from relative positions on the fronds. (A new blade is added daily at the frond tip.) Colony ages are estimated from colony size. Sample of Mar 22, 1971

\begin{tabular}{|c|c|c|c|c|c|c|c|c|c|c|c|}
\hline \multirow{2}{*}{$\begin{array}{l}\text { Blade } \\
\text { age } \\
(\mathrm{mo})\end{array}$} & \multirow{2}{*}{$\begin{array}{c}\text { Colony } \\
\text { age } \\
\text { (wk) }\end{array}$} & \multicolumn{2}{|c|}{ Frond A } & \multicolumn{2}{|c|}{ Frond B } & \multicolumn{2}{|c|}{ Frond C } & \multicolumn{2}{|c|}{ Frond D } & \multicolumn{2}{|c|}{ Frond $\mathrm{E}$} \\
\hline & & $\begin{array}{c}\text { No. } \\
\text { colonies }\end{array}$ & $\begin{array}{c}\text { No. } \\
\text { zooids }\end{array}$ & $\begin{array}{c}\text { No. } \\
\text { colonies }\end{array}$ & $\begin{array}{l}\text { No. } \\
\text { zooids }\end{array}$ & $\begin{array}{c}\text { No. } \\
\text { colonies }\end{array}$ & $\begin{array}{c}\text { No. } \\
\text { zooids }\end{array}$ & $\begin{array}{c}\text { No. } \\
\text { colonies }\end{array}$ & $\begin{array}{l}\text { No. } \\
\text { zooids }\end{array}$ & $\begin{array}{c}\text { No. } \\
\text { colonies }\end{array}$ & $\begin{array}{l}\text { No. } \\
\text { zooids }\end{array}$ \\
\hline \multirow{3}{*}{$0.5-1.5$} & $<2$ & 70 & 1776 & 95 & 2394 & 25 & 633 & 85 & 2151 & 75 & 1897 \\
\hline & $2-4$ & 0 & 0 & 63 & 5544 & 25 & 2200 & 68 & 5984 & 19 & 1672 \\
\hline & $>4$ & 0 & 0 & 0 & 0 & 0 & 0 & 0 & 0 & 0 & 0 \\
\hline \multirow{3}{*}{$1.5-2.5$} & $<2$ & 20 & 506 & 73 & 1847 & 175 & 4428 & 121 & 3061 & 638 & 16141 \\
\hline & $2-4$ & 103 & 9064 & 278 & 24464 & 550 & 48400 & 189 & 16632 & 224 & 19712 \\
\hline & $>4$ & 268 & 42076 & 12 & 1884 & 25 & 3925 & 0 & 0 & 22 & 3454 \\
\hline \multirow{4}{*}{$2.5-3.5$} & $<2$ & 0 & 0 & 0 & 0 & 0 & 0 & 0 & 0 & 0 & 0 \\
\hline & $2-4$ & 210 & 18480 & 280 & 24460 & 605 & 53240 & 283 & 24904 & 331 & 29128 \\
\hline & $>4$ & 950 & 149150 & 114 & 17898 & 0 & 0 & 122 & 19154 & 60 & 9420 \\
\hline & $\overline{\mathrm{X}}$ & 540 & 73864 & 305 & 26163 & 468 & 37608 & 289 & 23962 & 456 & 27141 \\
\hline
\end{tabular}

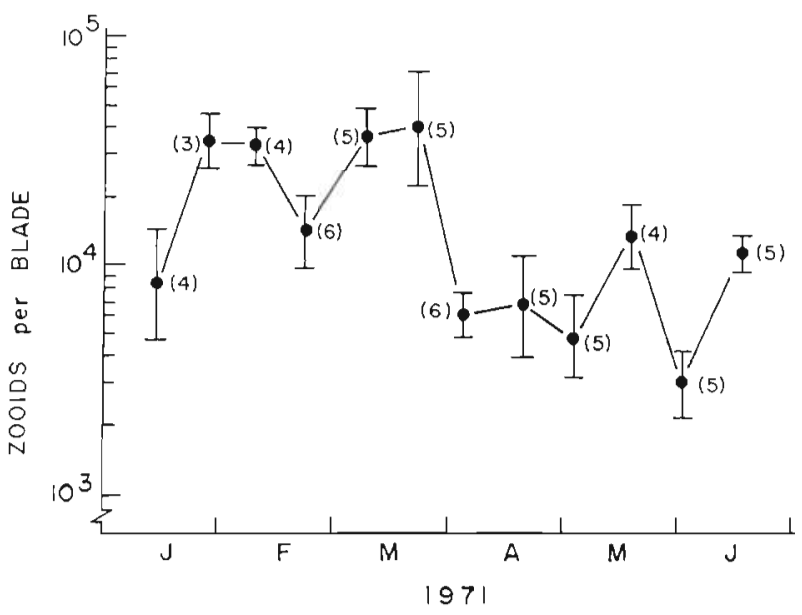

Fig. 1 Membranipora membranacea. Temporal variations of zooid densities per kelp blade $(\bar{x} \pm 1$ SD based on logtransformed data). Standard deviations determined from frond averages. Numbers in brackets: no. of fronds

Temporal variations in zooid density on individual kelp blades would follow the fate of colony cohorts due to the blade age-specific settling behavior of the cyphonautes. Fig. 2 shows temporal changes in zooid densities of colony cohorts from recruitment (defined as colonies between 0 and $2 \mathrm{wk}$ old) to $2 \mathrm{wk}$ later (when colonies reach 2 to 4 wk of age). Similarly, Fig. 3 shows the relation between recruitment and $4 \mathrm{wk}$ later (colony ages: 4 to $6 \mathrm{wk}$ ). Cohorts usually increase about 10 -fold in zooid density between recruitment and the second $2 \mathrm{wk}$ period of life and decline thereafter. (In general, no colonies more than 6 wk old occurred in the kelp bed samples due to fish predation [Bernstein \& Jung 1979].)

Linear regressions of Fig. 2 and 3 with $\log (n+1)$ transformations indicated that variations in zooid density increase with time (Table 2). Recruitment

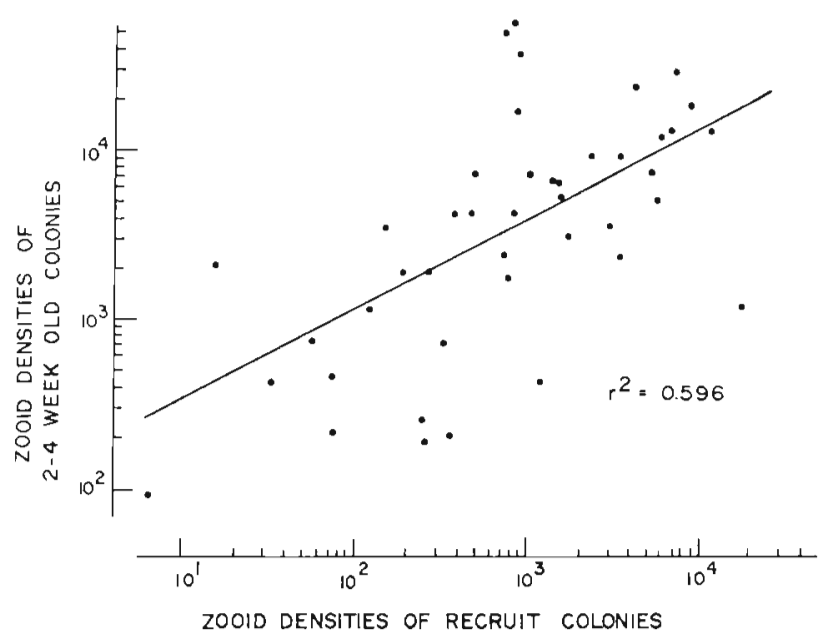

Fig. 2. Membranipora membranacea. Zooid densities (per blade) of colony cohorts at recruitment (colony ages: 0 to 2 wk) and 2 wk later (colony ages: 2 to 4 wk)

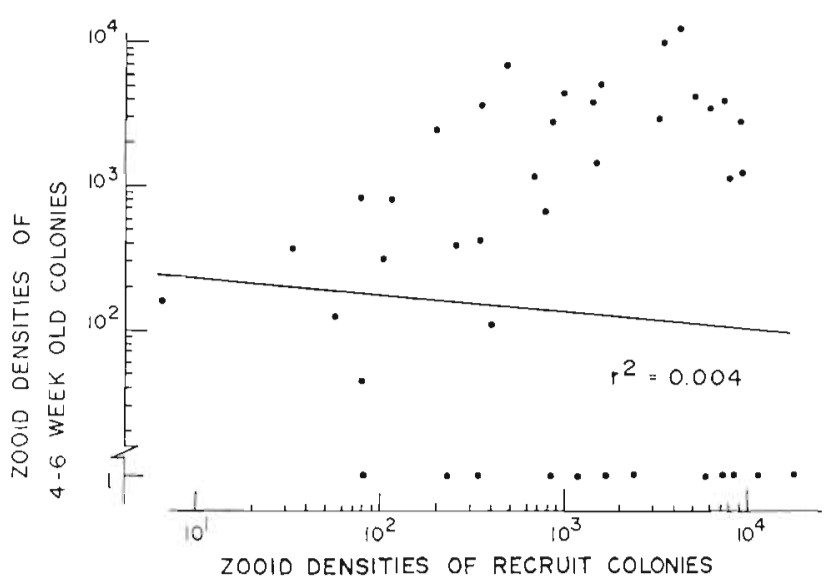

Fig. 3. Membranipora membranacea. Zooid densities (per blade) of colony cohorts at recruitment (colony ages: 0 to 2 $\mathrm{wk}$ ) and $4 \mathrm{wk}$ later (colony ages: 4 to $6 \mathrm{wk}$ ) 
Table 2. Analyses of variance of linear regressions of Fig. 2 and 3 . Number in brackets: standard deviations $=$ antiloge $[($ error MS) ${ }^{2}$ ]. $\cdots p \leq 0.001$; NS: not significant

\begin{tabular}{lrccccc}
\hline Source & $\mathrm{df}$ & \multicolumn{2}{c}{ Fig. 2 } & SS & Fig. 3 & MS \\
& & SS & MS & 1.982 & $1.982 \mathrm{NS}$ \\
Regression & 1 & 71.4015 & $71.4015 \cdots$ & 522.41 & $13.0602(37.1 \times)$ \\
Error & 40 & 48.434 & $1.2109(3.35 \times)$ & 524.392 & \\
Total & 41 & 119.8355 & & & \\
\hline
\end{tabular}

accounts for nearly $60 \%$ of the variability $\left(\mathrm{r}^{2}\right)$ in zooid densities 2 wk later and less that $1 \%, 4$ wk later. The relation is nonsignificant in the latter case, signifying that recruitment gives no indication of zooid densities $4 \mathrm{wk}$ in the future. However, it should be noted that the regression in Fig. 3 must be interpreted with caution because the $\log (\mathrm{n}+1)$ transformation assigns arbitrary values of zero for instances of no survivors (e.g. the horizontal line at the bottom of Fig. 3). Nevertheless, the conclusion that variability increases with time would be unaffected.

\section{Resource partitioning}

Doridella steinbergae and Corambe pacifica are highly episodic in their occurrence in kelp beds. When present, both species usually co-occur (Table 3B), indicating that a disjunct temporal partitioning of their prey resource does not account for their coexistence. The sequence of Membranipora membrancea colony growth and the subsequent appearance of the nudibranchs on the pier blades indicated that $C$. pacifica precedes $D$. steinbergae within a given episode of nudibranch infestation (Table 3A). Although field sampling intervals were too infrequent to allow a direct comparison with pier results, several characteristics indicate that a similar sequence occurs in the kelp canopy. Table $3 \mathrm{~B}$ shows that $C$. pacifica is relatively more abundant when total nudibranch abundances are low $(\mathrm{p}<0.05$, Kendall-tau Rank Correlation). The concurrent lack of nudibranch grazing damage and egg masses suggests that these samples represent the initial rather than terminal stages of nudibranch appearance. Thus, a 'temporal composite' of the field samples also indicates that $C$. pacifica settles first and is followed by larger numbers of $D$. steinbergae. This pattern could indicate resource partitioning.

Table 3. Doridella steinbergae (DS) and Corambe pacifica (CP). Densities of nudibranchs and their egg masses (per blade) in the pier experiment and field site. $\mathrm{n}$ : no. of blades

\begin{tabular}{|c|c|c|c|c|c|c|c|}
\hline \multirow[t]{2}{*}{ Date } & \multirow[t]{2}{*}{$\mathrm{n}$} & \multicolumn{4}{|c|}{ Nudibranchs } & \multicolumn{2}{|c|}{ Egg masses } \\
\hline & & $\mathrm{CP}$ & DS & Total & $\% \mathrm{CP}$ & Total & $\% \mathrm{CP}$ \\
\hline \multicolumn{8}{|l|}{ A. Pier blades } \\
\hline 6 Nov 1970 & 1 & 0 & 0 & 0 & - & - & - \\
\hline 19 Nov 1970 & 1 & 26 & 2 & 28 & 93 & 0 & - \\
\hline 24 Nov 1970 & 1 & 38 & 29 & 67 & 57 & 3 & 0 \\
\hline 30 Nov 1970 & 1 & 25 & 73 & 98 & 26 & 112 & 9 \\
\hline $2 \operatorname{Dec} 1970$ & 1 & 24 & 72 & 96 & 25 & 171 & 37 \\
\hline 5 Dec 1970 & 1 & 8 & 60 & 68 & 12 & 99 & 15 \\
\hline 10 Jun 1971 & 3 & 0 & 0 & 0 & - & - & - \\
\hline 21 Jun 1971 & 3 & 7.0 & 5.3 & 12.3 & 57 & 0 & - \\
\hline 25 Jun 1971 & 3 & 18.0 & 19.0 & 37.0 & 49 & 0 & - \\
\hline 28 Jun 1971 & 3 & 19.0 & 57.0 & 76.0 & 25 & 81 & 11 \\
\hline 1 Jul 1971 & 3 & 1.7 & 6.0 & 7.7 & 22 & 70 & 20.5 \\
\hline \multicolumn{8}{|l|}{ B. Field site } \\
\hline 25 Jan 1971 & 38 & 0.02 & 0.0 & 0.0 & 100 & 0.0 & - \\
\hline 15 Jun 1971 & 44 & 0.04 & 0.0 & 0.04 & 100 & 0.0 & - \\
\hline 18 May 1971 & 38 & 0.06 & 0.02 & 0.08 & 75 & 0.0 & - \\
\hline 3 Apr 1972 & 29 & 0.08 & 1.50 & 1.58 & 5 & 0.52 & 0 \\
\hline 1 Jun 1971 & 46 & 0.60 & 5.54 & 6.14 & 10 & 3.58 & 1 \\
\hline 5 Apr 1971 & 41 & 0.18 & 6.00 & 6.18 & 3 & 26.76 & 2 \\
\hline 29 Jun 1971 & 41 & 2.14 & 9.92 & 11.96 & 17 & 3.74 & 6 \\
\hline $22 \operatorname{Mar} 1971$ & 50 & 0.14 & 14.02 & 14.16 & 1 & 1.52 & 0 \\
\hline
\end{tabular}


The alternative possibility that the temporal difference in appearance of the nudibranchs results from an interaction between their life history pattern and the dynamics of their prey was evaluated with several simplifying assumptions: (1) veliger settling behavior involving threshold zooid densities governs the appearance of the nudibranchs; (2) individual kelp blades represent the appropriate spatial scale for predator-prey interactions; (3) temporal changes in zooid density on individual blades follow the fate of colony cohorts; and (4) growth and reproduction of nudibranchs cease when total consumption equals the standing stock of zooids. Given these conditions, at what zooid density would veliger settlement optimize the reproductive success of individual nudibranchs? I resolved this question by a case by case examination of 43 Membranipora membranacea cohort histories compiled over the 2 yr study period. I constructed cohort case histories by interpolating zooid densities between sampling periods. Given age-specific zooid requirements of Doridella steinberage and Corambe pacifica (Yoshioka 1986), I then determined whether settlement at a given zooid density would result in successful reproduction by a pair of conspecific nudibranchs.

Zooid densities and associated time spans for veliger settlement resulting in successful reproduction for a specific case history are shown in Fig. 4. Several general features are apparent: (1) reproduction is most successful if veligers settle prior to peak zooid densities; (2) Doridella steinbergae has a longer period of successful settlement; and (3) Corambe pacifica must settle at a relatively earlier time. Results compiled from all cohort histories are shown in Fig. 5, D. steinbergae enjoys a higher frequency of successful

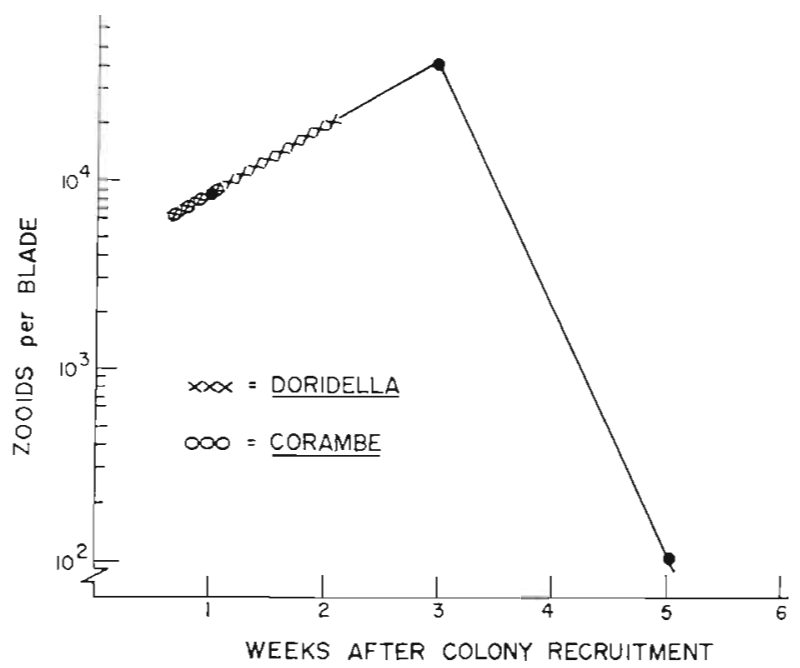

Fig. 4. Membranipora membranacea. Temporal variations in zooid densities of a cohort and time intervals when settlement of nudibranch veligers result in successful reproduction.

Samples of 18 Jan to 1 Mar 1970. (๑) Sampling intervals

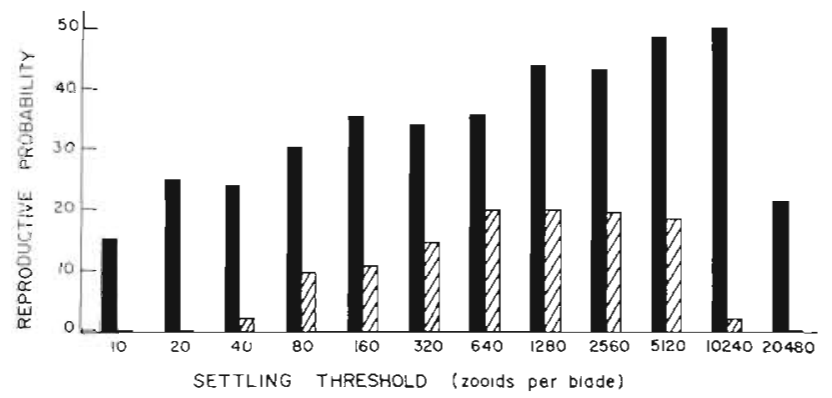

Fig. 5. Doridella steinbergae and Corambe pacifica. Probability of successful reproduction when veligers settle at various zooid densities. Solid bar: $D$. steinbergae; striped bar: $C$. pacifica

reproduction at all equivalent zooid densities. However, optimum success occurs at a higher zooid density (or later time of settlement) than C. pacifica (10240 against 900 zooids per blade).

\section{Environmental variability}

I assessed the effect of environmental variability by examining ratios of zooid densities relative to the abundance of the larger nudibranchs $(\geq 0.2 \mathrm{~cm})$. Smaller individuals were ignored due to their negligible impact on prey requirements (Yoshioka 1986). Variations in zooid/nudibranch ratios were examined both spatially (among blades) and temporally (among sampling periods). A complicating factor in this analysis is that temporal changes may also reflect 'successional' sequences occurring within episodes of nudibranch infestation. Fortunately, the occurrence of nudibranch egg masses gives an indication of the successional stage of nudibranch infestation due to their late appearance and persistence on kelp blades for 6 to $7 \mathrm{~d}$ thereafter. This sequence can be noted in the pier blades in Table 3A. I consequently used egg mass to nudibranch ratios (averaged over the entire sample) as an index of the successional stage of nudibranch infestation.

The regression between egg mass/nudibranch versus zooid/nudibranch ratios is given in Fig. 6 and Table 4 . The regression accounts for a significant $26 \%$ of the variability $\left(\mathrm{r}^{2}\right)$, indicating that a successional sequence is responsible for much of the variation in zooid to nudibranch ratios among sampling periods. The regression also displays significant deviations from linearity (Table 4). A visual inspection of the deviations of sample means from the regression suggests random heterogeneity around the line rather than a curvilinear relation (e.g. Sokal \& Rohlf 1981). If so, these variations would represent temporal environmental variability and its magnitude, estimated from a 


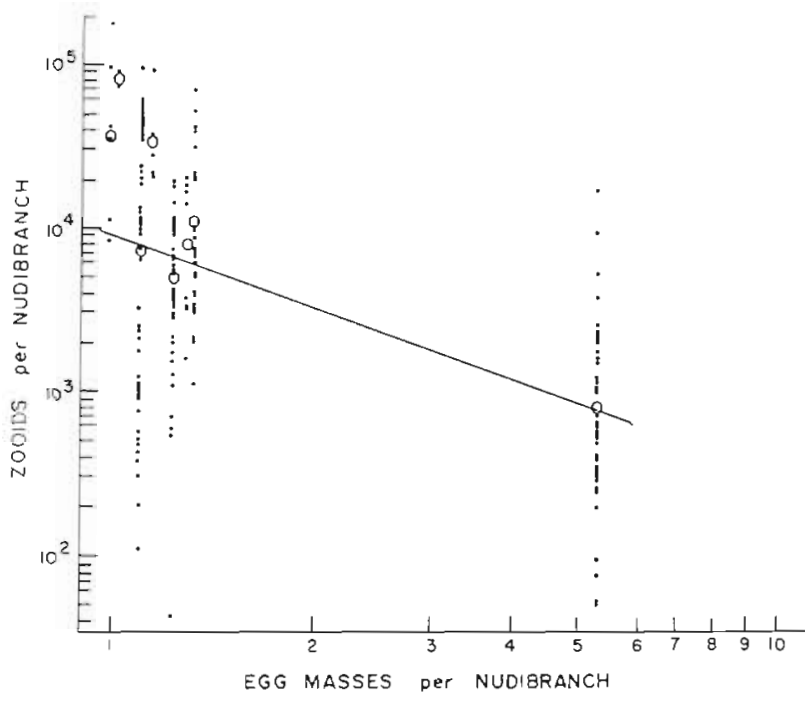

Fig. 6. Doridella steinbergae and Corambe pacifica. Relation of zooids per nudibranch ratios to egg masses per nudibranch ratios. Zooids per nudibranch ratios are $\log$ transformed and egg masses per nudibranch ratios are $\log (n+1)$ transformed.

(O) Sample means

Table 4. Analysis of variance of the linear regression of Fig. 6. $\cdots p \leq 0.01 ; \cdots p \leq 0.001$

\begin{tabular}{|lrrr|}
\hline Source & \multicolumn{1}{c}{ SS } & df & \multicolumn{1}{c|}{ MS } \\
\hline Dates & 182.05242 & 7 & $26.0077^{\cdots}$ \\
Regression & 137.0306 & 1 & $137.0306 \cdots$ \\
Deviation from linearity & 45.0236 & 6 & $7.5039 \cdots$ \\
Error & 333.1212 & 156 & 2.1354 \\
Total & 515.1754 & 163 & \\
& & & \\
\hline
\end{tabular}

components of variance model, corresponds to a standard deviation of 1.71 -fold. Each point in the regression represents zooid/nudibranch ratios on individual blades. Thus, the error mean square of the regression represents spatial (blade to blade) variability and corresponds to a standard deviation of 4.31 -fold. Fig. 6 also gives an alternative indication of spatial variability. Zooid/nudibranch ratios may range from about 50 to 100000 at a given time.

\section{DISCUSSION}

Settling behavior of Doridella steinbergae and Corambe pacifica

Previous reports have indicated highly selective settling behavior for Doridella steinbegae and Corambe pacifica. Both nudibranchs (MacFarland \& ODonoghue 1929, Lance 1962, Seed 1976) and their newly settled larvae (Yoshioka 1982a) have been noted only during periods of high prey abundance, suggesting that settling behavior involving threshold prey densities underlie their appearance in kelp beds. Bickell et al. (1981) have demonstrated highly selective settling behavior of $D$. steinbergae in the laboratory.

This study indicates that settlement of both nudibranchs is largely determined by the dynamics of their Membranipora membranacea prey. Zooid densities in the kelp bed are highly variable and are usually too low to support growth and reproduction by the nudibranchs. As a consequence, nudibranch settlement is limited to instances of high prey abundances. In fact nudibranchs are most successful if veliger settlement occurs prior to peak zooid densities because of the high prey requirements of older individuals. On a relative basis, Corambe pacifica settles before Doridella steinbergae because of higher age-specific zooid requirements and longer development time. A major consequence of earlier settlement is that $C$. steinbergae is subject to greater uncertainly in the availability of future resources.

\section{Resource partitioning}

Differences in appearance could conceivably reduce competition between the nudibranchs because Corambe pacifica may settle first, grow, and reproduce before the advent of the more efficient Doridella steinbergae. If true, this pattern would be consistent with resource partitioning theory. Further considerations indicate that this is not the case. For instance, the analysis of settling behavior demonstrates that the temporal difference can be explained independently of resource partitioning. Also, optimal success for $C$. pacifica and $D$. steinbergae occurs with settlement at prey densities of 900 and 10240 zooids per blade, respectively. This difference represents about $6 \mathrm{~d}$ in Membranipora membrancea colony growth (Yoshioka 1973) and is consistent with the results of the pier experiment. When coupled with age-specific feeding rates, this lag results in the maximum demand for zooids coinciding for the nudibranchs. Since the potential for competition would be increased rather than decreased, this result directly contradicts the expectations of resource partitioning theory.

This conclusion raises a paradox because settling behavior that increases the probability of competition is maladaptive. Environmental variability is probably responsible for the maintenance of this behavioral pattern. Because the fate of specific prey cohorts (hence, the possibility of competition) is unpredictable from the perspective of individual nudibranchs, selective forces underlying veliger settlement can only respond to a long term average of the dynamics of their 
prey in which the costs of competition have been incorporated (but see Lewontin 1966). Thus, environmental variability may prevent the evolution of fine tuning' mechanisms which minimize competition (Wiens 1977)

\section{Environmental variability}

Environmental variability provides an explanation for the coexistence of the nudibranchs. Corambe pacifica has the relative advantage if prey resources are nonlimiting because of greater fecundity while Doridella steinbergae benefits if resources are limiting because of greater reproductive efficiency (Yoshioka 1986). The regression analysis demonstrated significant differences in the relative abundances of prey among sampling periods, indicating that the relative success of $D$. steinberage and $C$. pacifica is unpredictable temporally. The examination of Membranipora membranicea cohort histories gives a similar result: zooid densities at the time of nudibranch recruitment represented a moderate to poor predictor of future zooid densities, indicating great uncertainty of which (if either) species will reproduce more successfully.

Superimposed upon temporal variations are large spatial (blade to blade) differences in relative prey abundances. Zooid/nudibranch ratios ranged from 50 to 100000 at a given time. The former value is less than the daily zooid requirements of larger nudibranchs (Yoshioka 1986) and indicates that no reproduction is possible; while the latter value represents more than a lifetime's supply of zooids and indicates maximum reproduction. Thus, spatial variations in zooid resources may range from the case where 'nobody wins' (no reproduction), to where Doridella steinbergae wins due to greater reproductive efficiency, and to where Corambe pacifica wins due to greater fecundity.

The role of temporal variability is reminiscent of Hutchinson's (1961) explanation for the 'paradox of the plankton' where coexistence results if time scales of environmental change and competitive exclusion are similar. Alternatively, the role of spatial variability is amenable to the analogous contemporaneous disequilibrium' hypothesis of Richerson et al. (1970). On a comparative basis, magnitudes of variability estimated by the regression analysis indicate the greater influence of spatial than temporal variations on nudibranch coexistence.

\section{Importance of exploitation competition}

More detailed insights into causal mechanisms underlying the coexistence of Doridella steinbergae and Corambe pacifica are provided by a random dispersal model by Skellam (1951). In this model coexistence may result even if one species 'always wins' by interference competition on isolated 'islands', if dispersal is random among islands and if the competitively inferior species has significantly higher reproduction. Coexistence occurs because random dispersal results in the inferior species being the only recruit on some islands. By analogy, kelp blades can be visualized as islands and $C$. pacifica would be the competitively inferior, but more fecund, species.

Doridella steinbergae and Corambe pacifica differ from Skellam's (1951) model in the presence of exploitation competition. Rather than one species always winning by interference, exploitation may enhance coexistence because of additional outcomes where 'nobody wins', D. steinbergae wins, and C. pacifica wins, depending upon the relative abundance of prey. (Situations where 'nobody wins' usually involve high absolute abundance of prey.) Thus, environmental variability manifested in 'errors of exploitation' (Istock 1973) may be more important than the equivalent 'errors of interference' in the coexistence of species. Miller (1969) has previously noted that coexistence is often associated with exploitation competition.

Gill (1974) has speculated that long-term competitive interactions favor the evolution of interference mechanisms. If so, what factors explain the absence of interference competition between the nudibranchs? Again, environmental variability plays a critical role. A major advantage of interference would be the protection and assurance of future food resources. This advantage is precluded from the nudibranchs because exogenous environmental factors largely control future zooid supplies. Thus, the association between environmental variability, exploitation competition and coexistence may not be entirely fortuitous for Doridella steinbergae and Corambe pacifica.

\section{Epilogue}

As a final note, it must be emphasized that environmental variability represents only a proximal explanation for coexistence. The possibility that the reproductive success of Doridella steinbergae and Corambe pacifica would be exactly equal by chance over space and time would be extremely unlikely. Any net advantage, however small, should eventually result in exclusion (Hardin 1960). Moreover, single species models by Skellam (1955), MacArthur \& Wilson (1967) and Pielou (1977) suggest that exclusion would still occur at random in the case of exact competitive equivalence. Recent 'lottery' models by Chesson \& Warner (1981), Sale (1982), Abrams (1984), and Warner \& 
Chesson (1985) indicate that long-term coexistence requires density (frequency) dependent mechanisms.

Acknowledgements. This study was conducted under the guidance of the late E. W. Fager. G. Breckon, D. Harvell, G. Owen, R. Strathmann and anonymous reviewers reviewed and improved previous drafts of the manuscript.

\section{LITERATURE CITED}

Abrams, P. A. (1984). Recruitment, lotteries, and coexistence in coral reef fish. Am. Nat. 123: 44-55

Bernstein, B. B., Jung, N. (1979). Selective pressures and coevolution in a kelp canopy community in southern California. Ecol. Monogr. 49: 335-355

Bickell, L. R., Chia, F. S., Crawford, B. J. (1981). Morphogenesis of the digestive system during metamorphosis of the nudibranch Doridella steinbergae (Gastropoda): conversion from phytoplanktivore to carnivore. Mar. Biol. 62: $1-16$

Chesson, P. H., Warner, R. R. (1981). Environmental variability promotes coexistence in lottery competition systems. Am. Nat. 117: 923-943

Connell, J. H. (1980). Diversity and the coevolution of competitors, or the ghost of competition past. Oikos 35: $131-138$

Dayton, P. K. (1973). Two cases of resource partitioning in an intertidal community: making the right choice for the wrong reason. Am. Nat. 107: 662-670

Gill, D. E. (1974). Intrinsic rate of increase, saturation density, and competitive ability. II. The evolution of competitive ability. Am. Nat. 108: 103-116

Hardin, G. (1960). The competitive exclusion principle. Science 131: 1292-1297

Harvell, C. D. (1984). Predator-induced defense in a marine bryozoan. Science 224: 1357-1359

Hutchinson, G. E. (1961). The paradox of the plankton. Am. Nat. 95: 137-145

Istock, C. A. (1973). Population characteristics of a species ensemble of waterboatmen. Ecology 54: 535-544

Lance, J. R. (1961). A distributional list of southern California opistobranchs. Veliger 4: 64-69

Lance, J. R. (1962). A new Stiliger and a new Corambella (Mollusca: Opistobranchia) from the N. W Pacific. Veliger 5: $33-38$

Lutaud, G. (1961). Contribution à l' étude du bourgeonnement et de la croissance des colonies chez Membranipora membranacea (Linnè) Bryozaire Chilostome. Ann. Soc. Roy. Belg. 91: 157-199
Lewontin, R. C. (1966). Is nature probabilistic or capricious? Bioscience 16: 25-27

MacArthur, R. H., Wilson, E. O. (1967). The theory of island biogeography. Princeton Univ. Press, Princeton

MacFarland, F. M., O Donoghue, C. H. (1929). A new species of Corambe from the Pacific coast of North America. Proc. Calif. Acad. Sci., Ser. 4. 18: 1-27

McBeth, J. W. (1968). Feeding behavior of Corambella stein bergae. Veliger 11: 145-146

Miller, R. S. (1969). Competition and species diversity Brookhaven Symp. Biol. 22: 63-70

Pielou, E. C. (1977). Mathematical ecology. Wiley, New York

Richerson, P., Armstrong, R., Goldman, C. R. (1970). Contemporaneous disequilibrium, a new hypothesis to explain the 'paradox of the plankton'. Proc natn. Acad. Sci. USA 67: $1710-1714$

Sale, P. F. (1982). Stock-recruitment relationships and regional coexistence in a lottery competition system: a simulation study. Am. Nat. 120: 139-159

Schoener, T. W. (1974). Resource partitioning in ecological communities. Science 185: 27-39

Seed, R. (1976). Observations on the ecology of Membranipora (Bryozoa) and a major predator Doridella steinbergae (Nudibranchiata) along the fronds of Laminaria saccharina at Friday Harbor, Washington. J. exp. mar. Biol. Ecol. 24: 1-17

Skellam, J. G. (1951). Random dispersal in theoretical populations. Biometrika 38: 196-218

Skellam, J. G. (1955). The mathematical approach to population dynamics. In: Cragg, J. B., Pirie, N. W. (ed.) The number of man and animals. Oliver and Boyd, Edinburgh, p. $31-46$

Sokal, R. R., Rohlf, F. J. (1981). Biometry. Freeman, San Francisco

Warner, R. R., Chesson, P. L. (1985). Coexistence mediated by recruitment fluctuations: a field guide to the storage effect. Am. Nat. 125: 769-787

Wiens, J. A. (1977). On competition and variable environments. Am. Sci. 65: 590-597

Yoshioka, P. M. (1973). The population dynamics and ecology of the encrusting ectoproct Membranipora serrilamella. Thesis, Univ. Calif., San Diego

Yoshioka, P. M. (1982a). Predator-induced polymorphism in the bryozoan Membranipora membranacea (L.). J. exp. mar Biol. Ecol. 61: 233-242

Yoshioka, P. M. (1982b). Role of planktonic and benthic factors in the population dynamics of the bryozoan $\mathrm{Mem}$ branipora membranacea. Ecology 63: 457-468

Yoshioka, P. M. (1986). Life history patterns of the dorid nudibranchs Doridella steinbergae and Corambe pacifica. Mar. Ecol. Prog. Ser. 31: 179-184 